\title{
Macroeconomic Fundamentals and Budget Deficit Nexus: Evidence from a Developing Economy
}

\author{
Gbenga Peter Sanusi \\ Department of Economics, \\ Anchor University, Lagos, Nigeria
}

DOI: https://doi.org/10.36941/mjss-2021-0036

Abstract

The increasing budget deficit of the Nigeria's government in the past few decades with its attendance impact on the economy is worrisome. This study examines the impacts of macroeconomic fundamentals on Nigeria's fiscal deficit. An error correction model was specified and estimated. In terms of sign and size, the result showed that, there is an inverse relationship between budget deficit and the external reserve. This implies that an increase in the external reserve, leads to a decrease in budget deficits. A unit increase in external reserves resulted in 12.4 percent fall in budget deficit. In contrast, however, national income and interest rate showed a positive relationship with budget deficit. Increase in income expands the potential and propensity to spend. Lenders are equally more disposed to lend to the government because of the presupposed economic prosperity. The lagged value of the error correction term has the expected inverse sign of -0.42, and highly significant. The negative value of the error correction model further supports the cointegration relationship among the variables. Thus, macroeconomic variables influence budget deficits. Economic policies which minimizes macroeconomic fluctuations is paramount in curbing the negative impacts of increasing government deficit in the economy.

Keywords: Budget Deficit, Macroeconomic variables, ECM, Nigeria

\section{Introduction}

Insight into the causes of increased government budget deficit will help to improve the understanding of the dynamics of how macroeconomic variables can affects budget balances. For instance, $\mathrm{Li}$ and Yin (2010) established a link between the exchange rate dynamics and macroeconomic fundamentals. Manipulation of macroeconomic variables in order to avoid the occurrence of unsustainable large deficits and debts is germane in developing nations. In Nigeria, this is of particular importance given the usual fiscal framework towards election years and the impact of debt burden on the welfare of the citizen.

Intervallic fluctuations in government sources of revenue and far-reaching corruption, as well as the government's huge investment activities, have been identified as the basic rational for the increased budget deficits over the years in Nigeria (Egwaikhide, 1991). Budget deficit occurs when a country's government expends more than it proceeds from taxes or other forms of revenue.

Most governments can choose to run moderate deficits for years. That's probable because they are more likely able to repay their creditors. Government is induced to incur more deficits in order to retain popular support by providing infrastructures and services. In a democratic polity, the elected 
politician will have to contend with spending as much as possible to continue being elected, and at the same time, ensuring that their lenders are not disappointed. However, the emergence of rising budget deficit in African countries is of concern to policy makers and international observers.

The inquiry into budget deficit is often traced to the Keynesian expenditure-led growth theory. It is based on the presumption that government spur aggregate demand through increased spending. For instance, in Nigeria, the federal government expenditures ${ }^{1}$ exceeded its revenues in the past three decades with the exception of 1995 and 1996 when surplus budget were pursued with the aim of expanding economic growth.

Obviously, increases in budget deficits have been associated with increase in debt service payments on public debt; declining tax revenue resulting from recession; corruption; increasing government spending especially during the year's preceding an election year. While budget deficits is not strange to developing economies like Nigeria, the disturbing fact is the rate, size and trend of it growth overtime. This has serious implications for every new government, investment decisions and citizen welfare of both the present and future generation.

The consequences of persistent government budget deficits and debt on macroeconomic variables cannot be underestimated in Nigeria. This has effects on macroeconomic variables such as interest rate, inflation, exchange rate, investment plan, and consumption, among others. The rising level of fiscal deficits has been identified as a major source of macroeconomic instability (Ezeabasili, Mojekwu, and Herbert, 2012)

The role that budget deficits play in an economy is huge (Murwirapachena, Maredza and Choga, 2013). However, most studies argued that deficit reduction is vital to the future growth of an economy, although, there is no general consensus in the literature. A lower budget deficits reduces real interest rates, leading to increase in investment and economic growth. Contrarily, non-nominal structural budget deficits can be good for an economy if it is used to stimulate expansion in output, consumption and investment through increase in real purchasing power which stimulate economic activities. The determinants and role of budget deficits have always been debated, however yielding different conclusions.

The financing of any form of fiscal deficits whether through loans or taxation involves the absorption of real resources that otherwise would have been available to the private sector. However, the classical school of thought holds the view that government activities are inherently bureaucratic and inefficient. This tends to suppress rather than promote growth. By and large, the question of whether government's fiscal policy stimulates growth or otherwise remains an empirical question to be resolved and lay to rest. An increased tax regime as a way of increasing government revenue could affect economic development negatively. Government spending that causes distortions to investment incentives to private agents can be counterproductive to economic expansion. Similarly, government excessive spending on consumption through budget deficit at the expense of investment is likely to hamper economic growth through raising inflation (Odhiambo et al. 2013).

Therefore, this study attempted an empirical analysis of the nexus between macroeconomic fundamentals and federal government budget deficit. This would provide an empirical insight for a critical appraisal of the relationship among the macroeconomic concepts.

Broadly, the study examined the effects of selected macroeconomic variables on budget deficits. More specifically, the paper aimed at achieving the following objectives, ascertain;

1. The effects of government income and external reserves on budget deficits, and;

2. Implications of interest and exchange rates on budget deficits in Nigeria.

This is an attempt to empirically estimate the macroeconomic determinants of budget deficit in the Nigeria, using a more recent macroeconomic data. The paper proceeds as follows: Section II gives an overview of the Nigeria economy during the last few years Section III is devoted to the review of selected literature. In Section IV, the model specification and methodology were pursued. In Section $\mathrm{V}$, the regression results and interpretations were presented. Finally, in Section VI, the conclusion and policy implications were discussed.

\footnotetext{
${ }^{1}$ both under the civilian and military rule
} 


\section{Stylized Facts}

The federal government influences aggregate demand through fiscal instruments such as budget deficits processes. Budget deficits affect macroeconomic variables such as interest rate, exchange rate, inflation and investment among others. In Nigeria, for instance, incidence of protracted budget deficit portends a severe adverse consequences in the near future. Oladipo and Akinbobola, (2011) noted that Nigeria started experiencing budget deficit in her budgetary system since 1957 prior to the civil war of 1967 to 1970 and became persistent in the 1970s. The trend has not change in any particular way over the years. Figure 1 shows an overview of changes in Nigeria's budget deficit in terms of percentages for the past 30 decades.

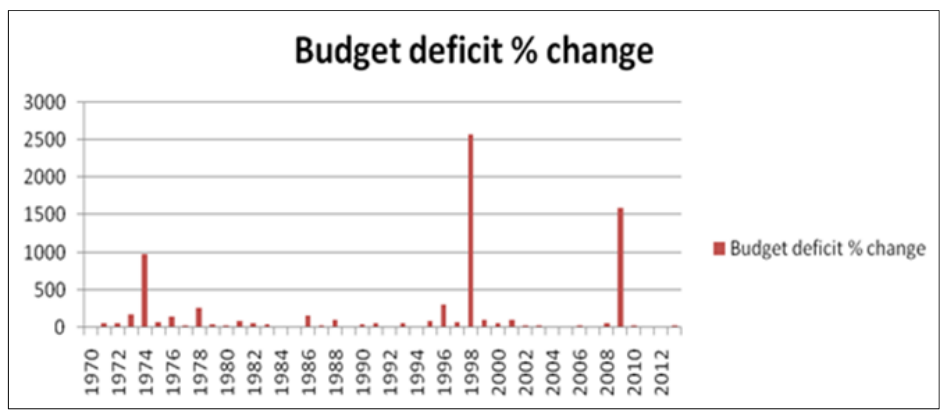

Figure 1: Percentage Change in Budget deficit, 1970-2012. Author's computation

Figure 1 shows that the percentages in budget deficit between 1970 and 2012 where minimal except in 1974, 1998 and 2009 when the percentage changes were well above 500 per cent. Historically, there was a sharp increase in world crude oil prices from \$3.9 to \$10 from 1973 to 1974 respectively. This sharp rise in the price of crude oil could have induced the propensity to increase fiscal deficits. However, both in 1998 and 2009, there was a fall in the prices of crude oil in the international market. For instance, there was 33 per cent fall in crude oil prices between 1997 and 1998. Again, the crude oil prices decreases from $\$ 100$ to $\$ 62$ from 2008 to 2009. This could have resulted into an economic shock and an upward review of budget in 1997 and 2009.

In 2012, the budget was a deficit of about 2.97 percent of GDP. 4.99 trillion naira budget was approved for 2013. There was a downward trend in the fiscal deficit within this period. The fiscal deficit in the 2014 annual budget rose marginally as against 1.85 percent in the 2013 budget which though, was still within the 3 percent of GDP threshold stipulated in Fiscal Responsibility Act of 2007. However, the annual budgets over the past few years have been rising.

Under some simplifying assumptions, budget deficit could be tax induced deficits or expenditure induced deficits. Both induced budget deficits have some implications on the economy. Three important views on the role of public debt as a causal factor of public expenditure growth include: one, the view that public deficits can significantly increase total-public spending. Two, rise in revenue as result of increase in output and a fall in consumer price index when a progressive tax structure regime is pursued will be a factor influencing growth in public expenditure. Finally, the role played by unfunded obligations of the government. The most cogent example of such obligations is the future pension payments in national retirement schemes. Such obligations are noticed to be accumulated pensions debts and therefore affect their economic activities in various ways, notably through savings decisions.

The extents to which the public debt issued to finance budget deficits will crowd out private investment will depend to a large extend on savings rates in the country. An economy where savings mobilization is higher than the marginal propensity to investment in the domestic market, can 
conveniently fund her domestic investment, while augmenting the government fiscal deficits.

The relationship between budget deficits and national income has been studied most extensively in the literature. Budget deficits stimulate economic activities in the country. In the absence of involuntary unemployment and when the economy is at full employment, any increase in aggregate demand occasioned by government budget deficits cannot expand output, but only to bring about an inflationary gap or high prices of goods and services. But in the case of unemployment and idle resources, real structural budget deficits can stimulate the aggregate output.

Theoretical macroeconomic underpinnings have divergent postulations on the impact of government budget deficits and debt accumulation in the economy (Diokno, 2007). A strand of these divergent positions opined that public debt curtails gross national savings and crowds out investment as well as negatively affecting economic growth. Another view, based on the Ricardian equivalence hypothesis asserts that, it is only the quantity of government expenditure which affects the economy, and not decision on if such purchases are financed through taxation or borrowing. Therefore, this suggests that government debt does not influence either national saving or capital accumulation.

\section{Literature Review}

Extant literature on government budget deficits can be viewed from two broad directions. While a few literature focused on the impact of government fiscal deficits on macroeconomic variables, some studies concentrated on how macroeconomic variables influences budget deficit. This section provides a brief review of the literature in examining the effect of macroeconomic variables on fiscal deficit.

Tujula and Wolswijk (2004) investigated empirically, the determinants of changes in OECD budgets balances. The authors highlighted that fiscal balances have deteriorated in recent years. The result of the empirical analysis showed that debt growth affects changes in budget balances. Specifically, the study found out that in Europe, election years contributes to the rise in budget deficits.

Focusing a country specific, Anwar and Ahmad (2012) examine the effects of political factors on government budget deficit in Pakistan economy between 1976 and 2009. Bounds testing methodology was employed to investigate the long-run equilibrium relationship between the budget deficit and the selected political variables. The empirical findings suggest the existence of a long-run relationship between political variables and government budget deficit. Besides, government size in Pakistan significantly contributed to the total budget deficit. However, democracy as an exogenous variable, shows a weaker influence in case of Pakistan in reducing budget deficit for the sample period.

Diokno, (2007), used national government account balance (NGAB) as a measure of fiscal balance, the author found out that the statistically significant determinants of budget deficits are: inflation, tax effort, domestic liquidity, and capital outlays. However, using the consolidated public sector fiscal position (CPSFP), the statistically significant determinants of fiscal balance were inflation, economic growth, capital outlays, tax effort, domestic liquidity and intergovernmental fiscal transfers (IRA).

Oladipo and Akinbobola (2011) evaluated the causal relationship between budget deficit and inflation in Nigeria: The study investigated the nature and direction of causality among the two variables. The Granger Causality test which was conducted showed only a unidirectional causal relationship from budget deficit to inflation in Nigeria. This result was found to be significant.

Looking at the South Africa, Murwirapachena, Maredza and Choga (2013) equally examine the economic determinants of budget deficits in South Africa. Budget deficit in South Africa has been increasing since 1980. This aroused a public debate on if budget deficits were the consequences of the magnitude of the economic problems that the government seeks to alleviate, poor governance or both. The study found that all the selected determinants in the Vector error correction model (VECM) have a positive effect on budget deficits except for external borrowing. Further, reserves and debts lead to a larger variation in budget deficit. Other factors include government investment, 
unemployment, and economic growth. Similarly, the relationship between fiscal deficits and economic growth in Kenya was underscored by the empirical investigation carried out by Odhiambo, Momanyi, Lucas, and Aila, (2012). The study showed a positive relationship between government budget deficits and aggregate output growth.

Moreover, Awe and Shina (2012), explore the nexus between budget deficit and inflation in the Nigerian Economy from 1980 to 2009. The authors examined whether budget deficit is inflationary. To determine the correlation that existed between the two macroeconomic variables, the study employed vector Error correction Mechanism (VECM) in analyzing the selected time series data. The result showed that budgets deficit leads to inflation as a result of increased money supply. This result was also supported by Ezeabasili, Mojekwu, and Herbert (2012), who attempted an empirical analysis of fiscal deficits and inflation in Nigeria using data over 1970-2006. The study re-examined fiscal deficit in the context of a developing country during a period of prolong inflation in the economy. The result of the co-integration technique revealed a positive relationship between inflation and fiscal deficits in Nigeria, though not statistically significant.

Contrary to previous evidences, Farajova (2011) investigates the relationship between budget deficit and macroeconomic fundamentals in Azerbaijan. Both the ARDL Co-integration methodology and Granger causality tests were applied to show evidence for both the short run and long dynamics between the variables. Evidence of long-run causality was found running from real interest rate, exchange rate, current account, inflation and GDP to budget deficit. A rather weak causal effect, however, was observed from inflation to budget deficit. Deficits, public debt dynamics, tax and spending multipliers examined by Denes, Eggertsson, and Gilbukh (2012) showed that increased sales taxes increases the budget deficit rather than reduce it. In effect, fiscal policy action is hugely dependent on the government policy regime.

Egwaikhide (1991), reconnoiter the determinants of fiscal deficits in a developing economy with evidence from Nigeria. The study pointed out that fiscal deficits have been a major facet of Nigeria's growth process and upsurge in fiscal deficits has been due to structural factors in the economy. Basically, the civil war in the second half of the 196os gave rise to huge budget deficits that were partly financed from credit or money creation. The oil boom of the 1970 s paves the way for the government revenue and expenditure to rise phenomenally. Consequently, as revenue increased, the size of the public sector expenditure increased as well. This led to a widening resource gap. The results of multiple regression analysis indicated that the most significant factors determining budget deficits in Nigeria have not been revenue instability and inflation, but rather, increased government participation and expenditure in the economy and the slow pace of growth in government revenue. To avoid a reoccurring debt crisis, financing of fiscal deficits through external loans should be properly managed.

Omoniyi, Olasunkanmi, Babatunde (2012), studied the effects of trade deficits and budget deficits in Nigeria with time series data between 1970 and 2008. The results from the study suggests a bidirectional causality between trade deficits and budget deficits in Nigeria. This suggests that appropriate government policy to reduce budget deficits could play an important role in curtailing trade deficit Nigeria. Besides, budget-cut, coherent export promotion, improved productivity and appropriate exchange rate policies could be complementary.

In conclusion, the review of the extant literature explored indicate that there is no concession on the direction and degree of the impact of macroeconomic variables on budget deficit. Depending on government policy and the economy being examined the results tends to varied.

Table 1: Summary of the Literature Reviewed

\begin{tabular}{|l|c|c|l|}
\hline Author(s) & Period/Country & Methodology & Empirical Result \\
\hline $\begin{array}{l}\text { 1. Tujula and } \\
\text { Wolswijk (2004) }\end{array}$ & $\begin{array}{c}\text { OECD countries. } \\
\text { OET-2002). 22 }\end{array}$ & OLS & $\begin{array}{l}\text { The result of the empirical analysis showed that debt growth affects } \\
\text { changes in budget balances. Budget balances are affected by } \\
\text { macroeconomic and political factors. In particular, the authors found } \\
\text { out that in Europe budget deficit increases during the election years. }\end{array}$ \\
\hline $\begin{array}{l}\text { 2. Anwar and } \\
\text { Ahmad (2012) }\end{array}$ & $\begin{array}{c}\text { (1976 to 2009). } \\
\text { Pakistan. }\end{array}$ & (ECM) /(ARDL) & $\begin{array}{l}\text { The results indicated that large government size led to increase in } \\
\text { government budget deficit. Democracy as a variable shows a weaker }\end{array}$ \\
\hline
\end{tabular}




\begin{tabular}{|c|c|c|c|}
\hline Author(s) & Period/Country & Methodology & Empirical Result \\
\hline & & & influence in case of Pakistan in reducing budget deficit for the sample period. \\
\hline $\begin{array}{l}\text { 3. Diokno, B. E. } \\
(2007)\end{array}$ & $\begin{array}{l}\text { (1981-2005) } \\
\text { Philippines }\end{array}$ & (2SLS) & $\begin{array}{l}\text { First, using national government account balance (NGAB), the study } \\
\text { found out that, the statistically significant determinants are: inflation, } \\
\text { tax effort, domestic liquidity, and capital outlays. Second, using the } \\
\text { consolidated public sector fiscal position (CPSFP), the statistically } \\
\text { significant determinants of fiscal balance were inflation, economic } \\
\text { growth, capital outlays, tax effort, domestic liquidity and } \\
\text { intergovernmental fiscal transfers (IRA). }\end{array}$ \\
\hline 4. Li and Yin (2010) & $\begin{array}{l}\text { (1999-2009) US } \\
\text { and EA }\end{array}$ & VAR & $\begin{array}{l}\text { The empirical analysis showed a near link between the exchange rate } \\
\text { dynamics and macroeconomic fundamentals. }\end{array}$ \\
\hline $\begin{array}{l}\text { 5. Kouassy and } \\
\text { Bohoun (1993) }\end{array}$ & $\begin{array}{c}(1970-1989) \text { Cote } \\
\text { dIvoire }\end{array}$ & OLS & $\begin{array}{l}\text { The result showed that Public investment (Ip) was positively linked to } \\
\text { fiscal deficits (FD), whereas, tax revenue is significantly sensitive to Ip in } \\
\text { the medium term. The study concluded that new fiscal policy will be } \\
\text { ideal for the country in the short-term, but subject to the choice of } \\
\text { instrument used. }\end{array}$ \\
\hline $\begin{array}{l}\text { 6. Murwirapachena, } \\
\text { Maredza and Choga } \\
(2013)\end{array}$ & $\begin{array}{c}(1980-2010) \text { South } \\
\text { Africa }\end{array}$ & VECM & $\begin{array}{l}\text { Selected determinants impacted positively on budget deficits. However, } \\
\text { external debt does not. Further, reserves and debts account for a larger } \\
\text { variation in budget deficit. Other factors which affects budget deficits } \\
\text { include government investment, unemployment, and economic growth. }\end{array}$ \\
\hline $\begin{array}{l}\text { 7. Oladipo and } \\
\text { Akinbobola (2011) }\end{array}$ & Nigeria & $\begin{array}{l}\text { Granger } \\
\text { Causality pair } \\
\text { wise test }\end{array}$ & $\begin{array}{l}\text { No causal relationship was found running from inflation to budget } \\
\text { deficit. But, a significant causal relationship from budget deficit to } \\
\text { inflation was observed. There is uni-directional causality from budget } \\
\text { deficit to inflation in Nigeria. }\end{array}$ \\
\hline $\begin{array}{l}\text { 8. Odhiambo, } \\
\text { Momanyi, Lucas, and } \\
\text { Aila (2012) }\end{array}$ & $\begin{array}{l}(1970-2007) \\
\text { Kenya }\end{array}$ & OLS & $\begin{array}{l}\text { Budget deficits and economic growth are positively related. Hence, } \\
\text { government delegated revenue authority could avoid crowding-out } \\
\text { private sector investment to improve the economic health of the } \\
\text { country. }\end{array}$ \\
\hline $\begin{array}{l}\text { 9. Awe and Shina } \\
\text { (2012) }\end{array}$ & $\begin{array}{l}(1980-2009) \\
\text { Nigeria. }\end{array}$ & VECM & $\begin{array}{l}\text { In Nigeria, a uni-directional causality running from budget deficit to } \\
\text { inflation was observed. }\end{array}$ \\
\hline $\begin{array}{l}\text { 10. Ezeabasili, } \\
\text { Mojekwu, and } \\
\text { Herbert. (2012) }\end{array}$ & $\begin{array}{c}\text { (1970-2006) } \\
\text { Nigeria }\end{array}$ & Cointegration & $\begin{array}{l}\text { The results revealed a positive but insignificant relationship between } \\
\text { inflation and fiscal deficits in Nigeria. Money supply is pro-cyclical and } \\
\text { growth rate is higher than the growth rate of inflation rate. }\end{array}$ \\
\hline 11. Farajova K. (2011) & $\begin{array}{l}(1992-2009) \\
\text { Azerbaijan. }\end{array}$ & $\begin{array}{c}\text { ARDL } \\
\text { Cointegration } \\
\text { Granger causality } \\
\text { tests }\end{array}$ & $\begin{array}{l}\text { Evidence of long-run causality runs from real interest rate, exchange } \\
\text { rate, current account, inflation and GDP to budget deficit. There was } \\
\text { also found evidence of short-run Granger causality running from real } \\
\text { interest rate and current account to budget deficit. Finally, there is no } \\
\text { short-run causality from interest rate to budget deficit. }\end{array}$ \\
\hline 12. Egwaikhide (1991) & Nigeria. & $\begin{array}{l}\text { Multiple } \\
\text { regression } \\
\text { analysis }\end{array}$ & $\begin{array}{l}\text { The results of multiple regression analysis indicate that the most } \\
\text { significant factors determining budget deficits in Nigeria have not been } \\
\text { revenue instability and inflation, but rather, increased government } \\
\text { participation and expenditure in the economy and the slow pace of } \\
\text { growth in government revenue. }\end{array}$ \\
\hline $\begin{array}{l}\text { 13. Omoniyi, } \\
\text { Olasunkanmi, } \\
\text { Babatunde (2012). }\end{array}$ & $\begin{array}{l}(1970-2008) \\
\text { Nigeria }\end{array}$ & $\begin{array}{c}\text { Pairwise causality } \\
\text { test and Error } \\
\text { Correction Model } \\
\text { (ECM) }\end{array}$ & $\begin{array}{l}\text { A bidirectional causality relationship exist between trade deficits and } \\
\text { budget deficits in Nigeria. Budget-cut, coherent export promotion, } \\
\text { improved productivity and appropriate exchange rate policies could be } \\
\text { complementary. }\end{array}$ \\
\hline
\end{tabular}

\section{Source: Author's compilation}

\section{Model Specification and Methododlogy}

\subsection{Theoretical Underpinnings}

Different theories have established the relationships between budget deficits and macroeconomic variables. While a few theoretical propositions focused on the impact of fiscal deficits on some selected economic variables, some others, examined how macroeconomic variables determine government deficits. The Standard model theory posits that the desired national saving falls because anticipated private saving tend to increase by less than the tax cut. In the long run, higher real interest rate crowds out investment, therefore the stock of productive capital is smaller. Because of intergenerational effects of tax burden, budget deficit leads to future fall in stock of productive capital. 
From the Ricardian stand point, a deficit-financed by a cut in current taxes for the purpose of managing government spending, could result into higher taxes in the future to make up for the initial cut. It follows that, a cut in taxes today, need be matched by a corresponding increase in the present value of future taxes. Ricardian Equivalence Theorem suggests that the substitution of a budget deficit for current government taxes does not affect the aggregate consumption. As such, government budget deficits and tax policy have equivalent effect on the economy (Diokno, 2007).

The Keynesian assumption suggests that aggregate consumption is responsive to changes in income. According to Keynesian model, an increase budget deficit by a certain point could cause aggregate output to increase by the ratio of the marginal propensity to save in the economy. The expansion in output increases the demand for money. Given that money supply is unchanging, interest rates would rise and private investment expenditure would invariably fall. Since output will fall with the rise in interest rate, the Keynesian multiplier effect is offset. Therefore, many Keynesians Economists posited that government deficits would not necessarily crowd out private investment. This present study is hinged on the Keynesian framework.

The study therefore, attempts to explore the empirical relationship between budget deficit and macroeconomics fundamentals by applying error correction model (ECM) technique. The study attempts to show if there is any existence of a causal relationship between budget deficit and macroeconomic fundamentals both in the short run and the long run. The simple regression model is as specified in equation 1:

$$
\begin{aligned}
& B U D=\varphi_{0}+\varphi_{1} L n I F L+\varphi_{2} L n G D P P C L+\varphi_{3} L n E X N R+\varphi_{4} R I R+\varphi_{5} L n D E B S B \\
& +\varphi_{6} L n G N X P L+\varphi_{7} L n T F C R+\varphi_{8} L n E X R+\mu
\end{aligned}
$$

Where, $L n B U D$ is the log of the budget deficit as the regressor. LnIFL is the inflation rate, GDPPCL, is the Gross domestic product, EXNR is the real exchange rate, RIR is the real interest rate, $L N G N X P L$ is the log of government expenditure, LNTFCR is the government total revenue, and LNEXR is the log of external reserve by the government.

With a little modification in equation 2, all variables remains as early defined except, $\operatorname{LnBUD}_{\mathrm{t}-1}$ which is the lag of the budget deficit.

$$
\begin{aligned}
& B U D=\varphi_{0}+\varphi_{1} B U D_{t-1}+\varphi_{2} L n I F L+\varphi_{3} L n G D P P C L+\varphi_{4} L n E X N R+\varphi_{5} R I R+\varphi_{6} L n D E B S \\
& +\varphi_{7} L n G N X P L+\varphi_{8} L n T F C R+\varphi_{9} L n E X R+\mu
\end{aligned}
$$

\subsection{Analytical Estimation Technique}

In this study, the model specification of budget deficit follows the work of Diokno (2007) with a little modification. The specification of the model considered the following variables, Budget Deficit (BD), as dependent variable; while inflation rate, Gross domestic product, the real exchange rate, real interest rate, government expenditure, government total revenue, and external reserve as independent variables.

\subsection{Data Sources}

The relevant data on budget deficit and macroeconomic fundamentals for Nigerian economy, were obtained from the World Development Indicator database, (WDI), 2013; Africa Development Indicator (ADI), 2012 and Central Bank of Nigeria Statistical Bulletin (CBN, 2009). The data employed for the empirical analysis are annual data covering the period 1970 to 2013.

\section{Empirical Analysis And Results}

This section focuses on the analysis and interpretation of the results estimated from the relationship between budget deficit and macroeconomic fundamentals. 


\subsection{Time Series Properties of Variables in the Model}

The results of the unit root tests are as presented in Table 2. The Augmented-Dickey fuller unit root test (null hypothesis $\left(\mathrm{H}_{\mathrm{o}}\right)$ ) states that, each of the selected variables has a unit root. This implies that variables were stationary at levels while the null hypothesis states that the variables are nonstationary. Accordingly, this implies that the ADF statistic should be greater than the critical value.

Table 2 shows the estimates of the Augmented Dickey Fuller (ADF) tests. It indicates that, all variables under consideration (exchange rate, external debt servicing, real GDP per capita, government expenditure and revenue, as well as inflation) were not stationary at levels, but were stationary after first differencing at one per cent significant level. This means that the series were integrated of order one --I (1). Therefore, all variables are stationary at first difference except BUD and RIR which were stationary at levels. The economic implication of variable stationarity implies that any disturbance or shock in the system, the variables move together at the same rate to equilibrium level. (Awe and Shina, 2012)

Table 2: Augmented Dickey-Fuller Unit Root Test Statistic

\begin{tabular}{|l|c|c|c|c|l|}
\hline Variable(s) & t-Statistic & $\begin{array}{c}\text { Test Critical } \\
\text { Values }\end{array}$ & Probability & $\begin{array}{c}\text { Order of } \\
\text { Integration }\end{array}$ & Remark \\
\hline BUD & -6.594 & $-3.596616 *$ & 0.0000 & $\mathrm{I}(\mathrm{o})$ & Null Hypothesis: BUD has a unit root. Stationary. \\
\hline D(LNDEBS) & -7.122 & $-3.596616 *$ & 0.0000 & $\mathrm{I}(1)$ & Null Hypothesis: D (LNDEBS) has a unit root. Stationary. \\
\hline D(LNEXNR) & -5.788 & $-3.596616 *$ & 0.0000 & $\mathrm{I}(1)$ & Null Hypothesis: D (LNEXNR) has a unit root. Stationary. \\
\hline $\mathbf{D}($ LNEXR) & -6.490 & $-3.596616 *$ & 0.0000 & $\mathrm{I}(1)$ & Null Hypothesis: D (LNEXR) has a unit root. Stationary. \\
\hline D(LNGDPPCL) & -4.713 & $-3.596616 *$ & 0.0004 & $\mathrm{I}(1)$ & Null Hypothesis: D(LNGDPPCL) has a unit root \\
\hline D(LNGNXPL) & -4.330 & $-3.596616 *$ & 0.0013 & $\mathrm{I}(1)$ & Null Hypothesis: D (LNGNXPL) has a unit root. Stationary. \\
\hline D(LNIFL) & -5.739 & $-3.600987 *$ & 0.0000 & $\mathrm{I}(1)$ & Null Hypothesis: D (LNIFL) has a unit root. Stationary. \\
\hline D(LNTFCR) & -4.950 & $-3.632900 *$ & 0.0003 & $\mathrm{I}(1)$ & Null Hypothesis: D (LNTFCR) has a unit root. Stationary. \\
\hline RIR & -5.714 & $-5.714182 *$ & 0.0000 & $\mathrm{I}(0)$ & Null Hypothesis: RIR has a unit root. Stationary. \\
\hline
\end{tabular}

Source: Author's Computation

In other to test for the long run relationship among the variables from the static regression, the linear combination of the variables residual's generated indicated that the residual were I (o). This implies that these variables are co-integrated. The unit root test result for the Residual is summarized Table 3.

Table 3: The Null Hypothesis

ECM has a unit root: Exogenous: Constant Lag Length: o (Automatic - based on AIC, maxlag=9)

\begin{tabular}{llll}
\hline \hline & & t-Statistic & Prob.* \\
\hline \hline Augmented Dickey-Fuller test statistic & -7.272841 & 0.0000 \\
\hline Test critical values: & $1 \%$ level & -3.600987 & \\
& $5 \%$ level & -2.935001 & \\
& $10 \%$ level & -2.605836 & \\
\hline \hline
\end{tabular}

Source: Computed from Data 


\subsection{Parsimonious Regression Results}

The result of the model estimated using ordinary least square (OLS) technique is shown in Table 4 . The short-run dynamics incorporates the lagged period residual. Thus, a parsimonious result was obtained through the process of sequential reduction.

Table 4: Pasimonious Regression Results

\begin{tabular}{|c|c|c|c|c|}
\hline Variable & Coefficient & Std. Error & t-Statistic & Prob. \\
\hline C & 31388.68 & 13152.19 & 2.386574 & 0.0233 \\
\hline $\operatorname{LNIFL}(-1)$ & -10.33240 & 2.925423 & -3.531935 & 0.0013 \\
\hline LNGDPPCL $(-2)$ & 6135.348 & 2013.094 & 3.047720 & 0.0047 \\
\hline LNEXNR & -12.35499 & 3.271306 & -3.776775 & 0.0007 \\
\hline LNDEBS & -223.4768 & 175.0238 & $-1.276 S_{37}$ & $0.2 \mathrm{~m}$ \\
\hline RIR & $7.48 S_{320}$ & 4906162 & 1.526309 & 0.1371 \\
\hline LNGNXPL $(-2)$ & -408.507 & 1842.497 & $-2.2298_{5} 8$ & 0.0331 \\
\hline $\operatorname{LNTFCR}(-2)$ & -166.5007 & 84.24657 & -1.976350 & 0.0572 \\
\hline LNEXR(-2) & -519.4551 & 143.5260 & -3.619241 & 0.0010 \\
\hline $\operatorname{ECM}(-1)$ & -0.427788 & $0.1606 \mathrm{SI}$ & -2.662344 & 0.0122 \\
\hline
\end{tabular}

Source: Author's Computation

Table 5: R-square and F-statistics

\begin{tabular}{|l|c|c|c|}
\hline R-squared & $\mathbf{0 . 5 9 1}$ & Akaike info criterion & $\mathbf{1 4 . 7 2 6}$ \\
\hline Adjusted R-squared & 0.473 & Durbin-Watson stat & $\mathbf{2 . 2 5 8}$ \\
\hline F-statistic & 4.992 & Prob(F-statistic) & 0.0003 \\
\hline
\end{tabular}

Source: Author's Computation

The chosen variables considered in determining the impact of macroeconomic variables on the budget deficit were found to be statistically significant at 5 per cent except debt servicing and real interest rate. Besides, it was not all the variables that have the hypothesized sign. In terms of sign and size, inflation in the previous year appears to move in opposite direction with the budget deficit. In other words, budget deficit in the current year is negatively influenced by the level of inflation in the preceding year. In fact, a unit increase in the level of inflation in the preceding year will bring about a 10 per cent decrease in the budget deficit in the current year.

Similarly, it is observed that there is an inverse relationship between budget and the external reserve. This implies that an increase in the external reserve, leads to a decrease in budget deficits. The result shows that a unit increase in external reserves resulted in 12.4 percent fall in budget deficit. By implication, excess of government expenditure over revenue are harmonized via the reserves where borrowing is not use as a source of funding. Debt servicing and government expenditure shows similarly trend. The negative relationship between budget deficit and total revenue generated by the government implies that increased government revenue induced more government spending. Besides, exchange rate variable implies that depreciation in exchange rate leads to increase in government deficit. Thus, this follows the early result shown that a fall in external reserve which could be due to a fall in the value currency increases public expenditures in terms of providing infrastructures, security, emolument and payment of both domestic and foreign obligations. This findings is supported by results obtained by Li and Yin (2010) and Murwirapachena, Maredza and Choga (2013). 
In contrast, however, national income and interest rate show a positive relationship with budget deficit. Increase in both the GDP and interest rate leads to increase in the fiscal deficit. Increase in income increases the potential and propensity to borrow. Lenders are equally more disposed to lend to the government because of the supposed economic growth through the sustained increase in the national income. Again, any rise in interest rate will tend to lead to a rise in the budget deficit through increase in the cost of borrowing. There is a direct link between domestic interest rate and the fiscal deficit.

The lagged of the error correction term $\left(\mathrm{ECM}_{\mathrm{t}-1}\right)$ has the expected inverse sign of -0.42, and highly significant (o.01). The negative value of the error correction term, otherwise refers to as the ECM supports the co-integration relationship between the variables. This implies that the speed of adjustment of about 0.42 or 42 per cent of any distortion in the short run were restored within a year.

The coefficient of determination measured by the $\mathrm{R}^{2}$ indicates that 59 per cent of the variations in the budget deficit were explained by the exogenous variables during the period. In addition, the Fstatistics relating to the goodness of fit, of 4.99 with a corresponding low probability of 0.00034 is an indication that the model is well specified. Finally, the Durbin-Watson statistics of 2.2 showed that the autocorrelation is not a problem in the specification.

\subsection{Other Diagnostic Tests}

Diagnostic tests were performed as presented in Tables 6 and 7 to validate the parameter adequacy of the model after the parsimonious regression. In specific term, the heteroskedasticity test using the Breusch-Pagan-Godfrey test, Breusch-Godfrey Serial Correlation LM and the asymptotic Jarque-Bera tests were performed. The residuals were normally distributed at 5 per cent level of significance using the Jarque-Bera test for residual normality. The B-G test is found to be highly significant with the probability greater than 5 per cent. The results of the tests therefore indicate the absence of serial correction. Conversely, the absence of white heteroskedasticity was however, violated.

In addition to the above tests, the CUSUM stability test was performed in order to establish the stability and reliability of the model. The graph showed that the parameter movements were within the critical lines at the 5 per cent level of significance. The ECM model is therefore stable. The CUSUM of Square and residual estimates falls between the critical lines except in 1997 when there was a little deviation in the CUSUM of Square. These indicate that the model is stable and robust.

Table 6: Heteroskedasticity Test: Breusch-Pagan-Godfrey

\begin{tabular}{|l|l|l|l}
\hline F-statistic & 3.024152 & Prob. F(9,31) & 0.0104 \\
\hline
\end{tabular}

Source: Author's Computation.

Table 7: Breusch-Godfrey Serial Correlation LM/ Jarque-Bera Test:

\begin{tabular}{|c|clc|}
\hline F- statistic & 2.68 & Prob. F(2,29) & 0.0854 \\
\hline Jarque-Bera & 4.77 & Prob. & 0.092 \\
\hline
\end{tabular}

Source: Author's Computation.

The CUSUM test (Figure 2) was employed to confirm the stability of the coefficients in the model. Thus, confirming the long-run structural stability for the model's coefficients.

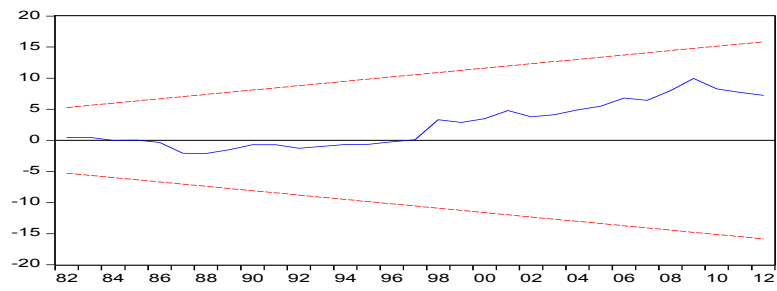

Figure 2: CUSUM Test 


\section{Conclusion and Policy Recommendations}

Budget deficit is affected by macroeconomic variables. Budget deficit in the current year is negatively influenced by the level of inflation in the preceding year. It was observed that there was an inverse relationship between budget deficit and the external reserve. This implies that an increase in the budget deficit led to a depletion of the external reserve. Debt servicing and government expenditure shows similar trend. By implication, debt re-payment and debt servicing reduces external reserves. Again, a fall in external reserves could induce budget deficit. The negative relationship between budget deficit and total revenue generated by the government shows that decrease in government revenue leads to increase in budget deficit.

In contrast, however, national income and interest rate showed a positive relationship with budget deficit. Increase in both the GDP and interest rate led to increase in the fiscal deficit. Increase in income increases the potential and propensity of borrowing. Lenders are equally more disposed to lend to the government because of the supposed economic growth through the sustained increase in the national income. In addition, any rise in interest rate will tend to lead to a rise in the budget deficit through increase in the cost of borrowing for the purpose of executing government responsibility. There is a direct link between domestic interest rate and the fiscal deficit.

Therefore, policymakers needs to avoid policies that could negatively affects the above macroeconomic fundamentals which has direct implications on economy via expansion in the budget deficit. There is need for concerted efforts to reduce the increasing rate of budget deficit in the developing countries. These efforts will help to attain sustainable economic growth and avert the pain of shifting current debt burden to the unborn or future generation.

\section{References}

Anwar M. and Ahmad M. (2012). Political Determinants of Budget Deficit in Pakistan: An Empirical Investigation paper 135 Hamburg Institute of International Economics (HWWI). Heimhuder Str. 71 | 20148 Hamburg | Germany.ISSN 1861-504X

Awe A.A and Shina O.S (2012). The Nexus between Budget Deficit and Inflation in the Nigerian Economy (1980 2009). Research Journal of Finance and Accounting ISSN 2222-2847 (Online) Vol 3, No 10, ISSN 2222-1697

Denes, M., Eggertsson, G.B and Gilbukh, S. (2012). Deficits, Public Debt Dynamics, and Tax and Spending Multipliers. Federal Reserve Bank of New York Staff Reports, no. 551 February 2012; revised September 2012

Diokno, B.E. (2007). Economic and fiscal policy determinants of public deficits: The Philippine case, Discussion paper // School of Economics, University of the Philippines, No.2007,02. http://hdl.handle.net/10419/46651.

Egwaikhide, F. O.(1991). Determinants of fiscal deficits in a developing economy: evidence from Nigeria. The Nigerian Journal of Economic and Social Studies, Ibadan Volume: 33 Issue: 3 Pages: 177-189

Ezeabasili, V.N Mojekwu, J.N and Herbert, W.E (2012). An Empirical Analysis of Fiscal Deficits and Inflation in Nigeria: International Business and Management. Vol. 4, No. 1, 2012, pp. 105- 120. ISSN 1923-841X [Print] ISSN 1923-8428[Online]

Farajova K. (2011). Budget Deficit and Macroeconomics Fundamentals: The case of Azerbaijan: International Journal of Economic Sciences and Applied Research 4 (2): 143-158 Eastern Macedonia and Thrace Institute of Technology P.C. 65404, Kavala, Greece.

Kouassy Q. and Bohoun B., (1993). The determinants of fiscal deficit and fiscal adjustment in Cote d'Ivoire. AERC Research Paper 15 African Economic Research Consortium, Nairobi 1993 ISBN 1-897621-08-6. University of Oxford, England.

Li J. and Yin, W. (2010). Macroeconomic Fundamentals and the Exchange Rate Dynamics: A No- Arbitrage MacroFinance Approach. Bocconi Economics workshop, ESSE Business School Finance seminar, Cambridge Macroeconomic workshop.

Murwirapachena, G. Maredza A. and Choga I. (2013). The Economic Determinants of Budget Deficits in South Africa. Mediterranean Journal of Social Sciences. MCSER Publishing, Rome-Italy. Vol 4 No 13. ISSN 20399340

Odhiambo O.S, Momanyi G., Lucas O., and Aila, F.O. (2013). The Relationship between Fiscal Deficits and Economic Growth in Kenya: An Empirical Investigation: Greener Journal of Social Sciences ISSN: 2276-78oo Vol. 3 (6), pp. 306-323, July 2013. 
Oladipo S. O and Akinbobola T. O. (2011), Budget Deficit and Inflation in Nigeria: A Causal Relationship, Journal of Emerging Trends in Economics and Management Sciences (JETEMS) 2 (1): Scholarlink Research Institute Journals, 2011 (ISSN: 2141-7024)

Omoniyi, O.S Olasunkanmi, O.I and Babatunde O.A (2012) Fiscal Policy Variables-Growth Effect: Hypothesis Testing. American Journal of Business and Management Vol. 1, No. 3, 2012, 100- 107. ISSN 2167-9606 Print/ ISSN 2167-9614.

Tujula M. and Wolswijk G. (2004) What Determines Fiscal Balances? An Empirical Investigation in Determinants of changes in OECD Budget Balances. Working paper seriesNo.422. European Central Bank, 2004 Kaiserstrasse 2960311 Frankfurt am Main, Germany http://ssrn.com/abstract_id=631669.

\section{Appendix:}

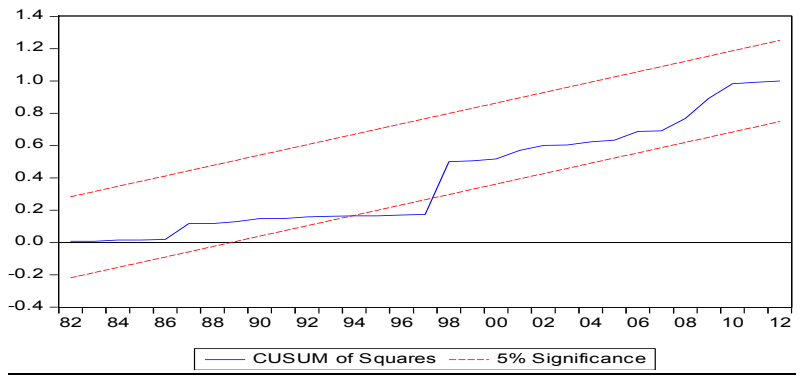

Figure 6.3: CUSUM of Squares
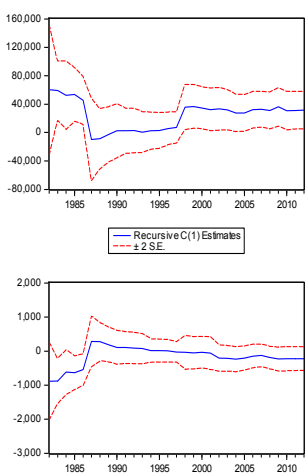

- Recursive C(5) Estimates

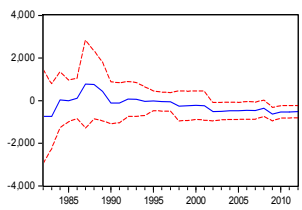

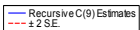

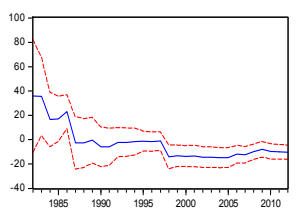

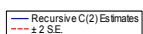

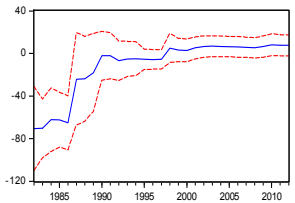

\begin{tabular}{|l}
\hline Recursive C(6) Estinates \\
\hline -- \pm 2 S.E. \\
\hline
\end{tabular}

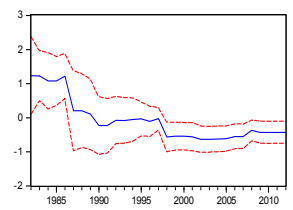

-Recursive C(10) Esimales
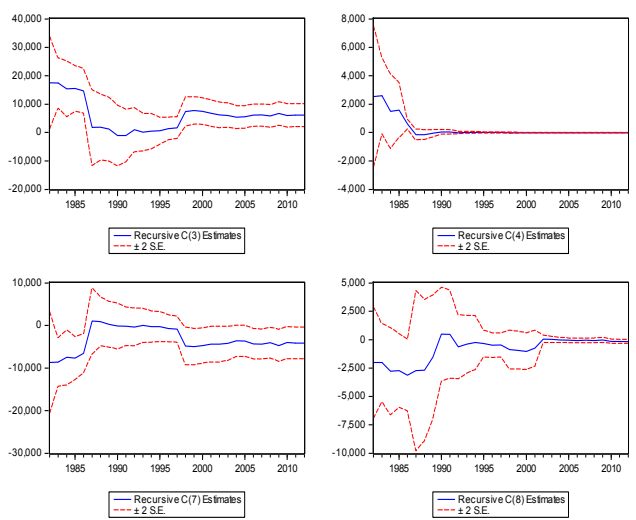